University of Nebraska - Lincoln

DigitalCommons@University of Nebraska - Lincoln

Exploring Spatial Distributions of Larval Yellow Perch Perca

flavescens, Bluegill Lepomis macrochirus, and Their Prey in

Relation to Wind.

\author{
Mark A. Kaemingk \\ University of Nebraska - Lincoln, mkaemingk2@unl.edu \\ Jeffrey C. Jolley \\ David W. Willis \\ Brian DS Graeb
}

Follow this and additional works at: https://digitalcommons.unl.edu/natrespapers

Part of the Natural Resources and Conservation Commons, Natural Resources Management and Policy Commons, and the Other Environmental Sciences Commons

Kaemingk, Mark A.; Jolley, Jeffrey C.; Willis, David W.; and Graeb, Brian DS, "Exploring Spatial Distributions of Larval Yellow Perch Perca flavescens, Bluegill Lepomis macrochirus, and Their Prey in Relation to Wind." (2011). Papers in Natural Resources. 710.

https://digitalcommons.unl.edu/natrespapers/710

This Article is brought to you for free and open access by the Natural Resources, School of at DigitalCommons@University of Nebraska - Lincoln. It has been accepted for inclusion in Papers in Natural Resources by an authorized administrator of DigitalCommons@University of Nebraska - Lincoln. 


\title{
Exploring spatial distributions of larval yellow perch Perca flavescens, bluegill Lepomis macrochirus and their prey in relation to wind
}

\author{
M. A. KaemingK*†, J. C. Jolley* ${ }^{*}$, D. W. Willis* and B. D. S. Graeb* \\ *Department of Wildlife and Fisheries Sciences, South Dakota State University, Brookings, \\ SD 57007, U.S.A. and $\ddagger$ United States Fish and Wildlife Service, Columbia River Fisheries \\ Program Office, 1211 SE Cardinal Court, Suite 100, Vancouver, WA 98683, U.S.A.
}

(Received 2 September 2010, Accepted 25 January 2011)

\begin{abstract}
The objectives of the present study were to determine if spatial differences existed between zooplankton, larval yellow perch Perca flavescens and bluegill Lepomis macrochirus $(<13 \mathrm{~mm}$ total length, $L_{\mathrm{T}}$ ) in Pelican Lake (332 ha), NE, U.S.A. It was hypothesized that wind could act as a transport mechanism for larval fishes in this shallow lake, because strong winds are common at this geographic location. Potential spatial differences were explored, relating to zooplankton densities, size structure and densities of larval P. flavescens and L. macrochirus. Density differences (east $v$. west side of the lake) were detected for small- (two occasions), medium- (two occasions) and large-sized (one occasion) L. macrochirus larvae. No density differences were detected for small $P$. flavescens larvae; however, densities of medium- and large-sized P. flavescens were each higher on the west side of the lake on two occasions. There was no evidence that larval P. flavescens and L. macrochirus distributions were related to wind because they were not associated with large wind events. Likewise, large wind event days did not result in any detectable spatial differences of larval $P$. flavescens and L. macrochirus densities. There appeared to be no spatial mismatch between larval densities and associated prey in the years examined. Thus, wind was not apparently an influential mechanism for zooplankton and larval $P$. flavescens and L. macrochirus transport within Pelican Lake, and spatial differences in density may instead be related to vegetation and habitat complexities or spawning locations within this shallow lake.

(C) 2011 The Authors
\end{abstract}

Journal of Fish Biology @ 2011 The Fisheries Society of the British Isles

Key words: habitat; larval fishes; larval transport; match-mismatch; zooplankton.

\section{INTRODUCTION}

The recruitment process in fishes is often complex and arguably one of the least understood dynamic rate functions (i.e. recruitment, growth and mortality) in fisheries science. Factors thought to influence recruitment of fishes operate on several spatial and temporal scales and include prey availability (Welker et al., 1994), predation (Miller et al., 1988; Santucci \& Wahl, 2003), environmental conditions such as wind, temperature and precipitation (Pope et al., 1996; Ward et al., 2004) and the timing of reproduction (Beard, 1982; Cargnelli \& Gross, 1996; Garvey et al., 2002), among

\footnotetext{
$\dagger$ Author to whom correspondence should be addressed. Tel.: +1 605688 6577; email: mark.kaemingk@
} sdstate.edu 
others. Isolating which factors are most important remains difficult, because many of these variables probably interact and affect recruitment differentially, depending on species, habitat and developmental stage (e.g. egg, larva and juvenile).

Wind direction and velocity, among the environmental variables used to explain recruitment variability, have been negatively related to the survival of fish eggs and larvae (Clady \& Hutchinson, 1975; Clady, 1976; Kallemeyn, 1987; Ward et al., 2004). High winds causing wind-induced waves and currents directly dislodge and destroy fish eggs by physical destruction on hard substrata (Clady \& Hutchinson, 1975; Roseman et al., 2001). In addition, high winds can affect temperature regimes experienced by eggs and pro-larvae before the fishes become limnetic and negatively influence survival in the early stages of development (Clady, 1976). While previous studies speculated that wind may act as a transport mechanism for fish eggs, few studies have attempted to examine spatial differences in larval fishes and relate them to wind direction and velocities.

Wind has been negatively related to larval abundances in several species of fishes in the mid-west of the U.S.A., most probably because high sustained winds are common and little protection from these wind events is provided in this geographic region. Winds in this region may induce strong waves and currents that potentially dislodge eggs or cause transportation of larvae to unfavourable temperature regimes (Mitzner, 1991; Ward et al., 2004; Phelps et al., 2008). Recruitment for some species may be established during the early stages of egg and larval development in this region (Anderson et al., 1998; Isermann \& Willis, 2008). Although wind has been negatively related to larval abundances and adult year class strength and is considered an important factor that may regulate recruitment for some fishes in the mid-west (Mitzner, 1991; Ward et al., 2004; Phelps et al., 2008), the mechanism involved in this process has not been identified. Therefore, further examination in exploring relationships between wind and early life stages of fishes is warranted.

Most larval fishes are dependent on zooplankton as a food source during the early stages of life. Zooplankton densities may vary spatially and temporally, and at low prey densities growth and mortality of larval fishes can be negatively affected (Puvanendran \& Brown, 1999; Seljeset et al., 2010). Several authors suggested that at low zooplankton densities, larval fish survival is suppressed due to starvation (Werner \& Blaxter, 1980; Eldridge et al., 1981; Li \& Mathias, 1982; Dettmers et al., 2003); this prey density threshold is, however, based on a minimum of $10 \%$ larval survival in the laboratory (Saksena \& Houde, 1972). Tsai (1991) argued, however, that the density threshold is arbitrarily assigned and that some fishes within a population may require higher or lower densities than 100 organisms $1^{-1}$. As a result, it remains difficult to determine the lower threshold required for the recruitment of larval fishes in relation to prey availability, but in general, survival is positively related to prey availability (Tsai, 1991; Welker et al., 1994).

For larval fishes to successfully recruit to the next life stage, it is critical that adequate prey is available and that both predator and prey overlap spatially and temporally. Much research focused on the temporal overlap of these resources (e.g. match-mismatch hypothesis; Cushing, 1975, 1990). More recent work has incorporated the dimension of space into the match-mismatch framework (Chick \& Van Den Avyle, 1999; Romare et al., 2003; Beauchamp et al., 2004) in which both space and time are realized as important variables while relating zooplankton availability to larval fish growth and survival to better understand the recruitment process in fishes. 
Both yellow perch Perca flavescens (Mitchill 1814) and bluegill Lepomis macrochirus (Rafinesque 1819) exhibit similar ontogenetic habitat shifts, where eggs are deposited within the littoral zone and upon hatching the larvae distribute across the limnetic zone (Werner, 1967; Whiteside et al., 1985). While in the limnetic zone, both species depend on zooplankton to grow and ultimately survive to the next life stage (Welker et al., 1994; Graeb et al., 2004). Therefore, it is important to more fully understand the spatial distribution of both P. flavescens and L. macrochirus larvae and their associated prey as a potential spatial mismatch may result in lower survivorship at the larval stage.

Jolley et al. (2010) explored temporal match-mismatch with prey for larval P. flavescens and L. macrochirus in Pelican Lake. These authors did not, however, examine spatial overlap with prey. Therefore, the objectives were to determine if spatial differences existed in density, size and prey of larval P. flavescens and L. macrochirus in Pelican Lake, NE, U.S.A. from 2004 to 2008. If differences in spatial larval density existed, then those differences were related to wind effects under the assumption that wind could act as a transport mechanism in this shallow, windswept lake. If wind does act as a transport mechanism, it may cause larval fish densities to be higher in areas with lower densities of prey, resulting in slower growth and ultimately starvation. Larval fishes may be transported similarly to their prey; a complete spatial overlap would, however, assume that the point of origin prior to a wind event for both fishes and zooplankton is the same. Differences in spatial larval fish sizes were examined to potentially elucidate if smaller larvae are more likely to be transported by wind-induced waves.

\section{MATERIALS AND METHODS}

Pelican Lake is a 332 ha, shallow (mean depth $=1.3 \mathrm{~m}$ ) natural lake in the Sandhills region of north central Nebraska, U.S.A., within the Valentine National Wildlife Refuge (Fig. 1). Total vegetation coverage during peak foliage (emergent and submergent combined) ranged from 40 to 52\% during midsummer in 2004 and 2005 (Jolley, 2009). Emergent vegetation is mainly concentrated along the shoreline extending upward of 30-40 m into the lake, with several isolated patches in the main basin of the lake. Submergent vegetation primarily exists on the northern portion of the main basin due to a shallow depth contour and in most cases does not reach the water surface. This region also experiences high sustained wind velocities (some daily means $>26.3 \mathrm{~km} \mathrm{~h}^{-1}$, with prevailing winds from the north-west) throughout much of the year, but especially during the spring (Dewey, 1977; Wilhite \& Hubbard, 1989). Pelican Lake has a north-west to south-east orientation, deviating $c .25^{\circ}$ from a straight east to west position (Fig. 1).

Larval fishes were collected every 10 days from late April to late August or early September at Pelican Lake from 2004 to 2008. Recently hatched larval P. flavescens and L. macrochirus (total length, $L_{\mathrm{T}} \leq 13 \mathrm{~mm}$ ) were sampled and indexed using a surface trawl with a $0.76 \mathrm{~m}$ diameter opening and $1000 \mu \mathrm{m}$ mesh (bar measure) towed in large ellipses. Trawl duration was $c .3-5 \mathrm{~min}$ at an estimated speed of $1.75 \mathrm{~m} \mathrm{~s}^{-1}$. The lake was divided into 16 quadrats (each c. 20.75 ha; eight east and eight west) and 10 of those quadrats were randomly chosen and trawled on each occasion. The amount of water volume trawled was calculated using a flowmeter (Ocean Test Equipment, Inc.; www.oceantestequip.com) in the mouth of the trawl. All larval samples were preserved in $70 \%$ ethanol and returned to the laboratory for identification and further analysis. All field data collection occurred during daylight hours.

Larval fishes were identified to genus using identification keys (Auer, 1982; Holland-Bartels et al., 1990). All larvae were enumerated and up to 200 randomly chosen fish per sample for each species were measured $\left(L_{\mathrm{T}}\right)$ from each quadrat sampled. Larvae of $L_{\mathrm{T}} \leq 13 \mathrm{~mm}$ were 
(b)

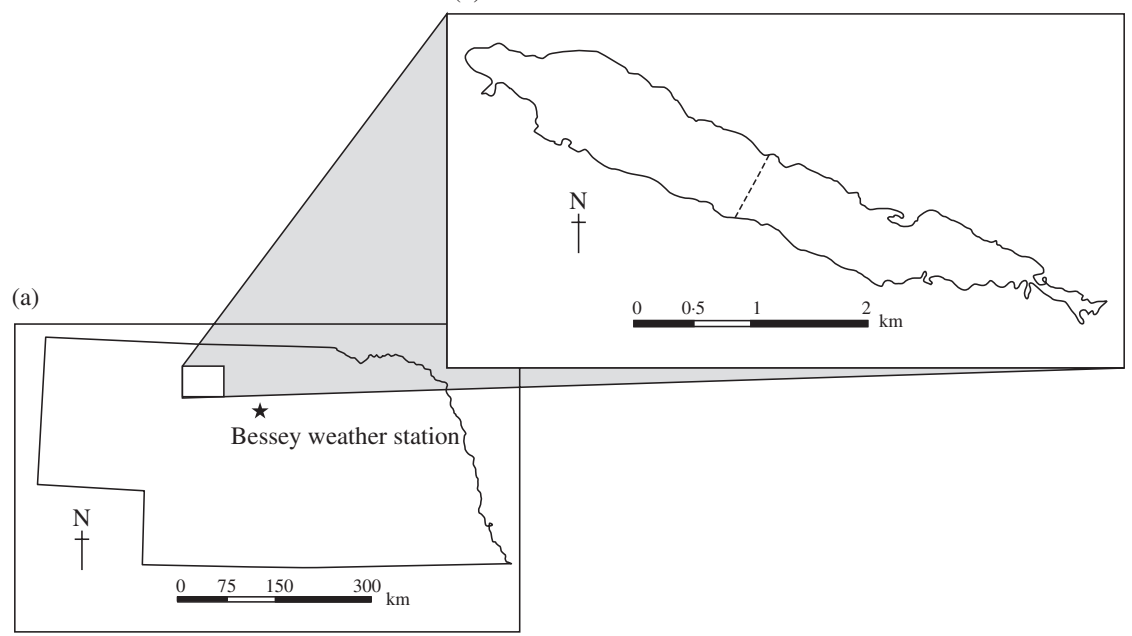

FIG. 1. Nebraska, U.S.A., and location of (a) the Bessey weather station ( $\star$ ) and (b) Pelican Lake (_.-dividing line between the east and west basins of the lake).

used to calculate larval abundances; fishes of $L_{\mathrm{T}}>13 \mathrm{~mm}$ were considered juveniles. Garvey et al. (2002) characterized L. macrochirus larvae as those $<15 \mathrm{~mm} L_{\mathrm{T}}$. Lepomis macrochirus generally begin a migration to littoral habitats between 12 and $20 \mathrm{~mm} L_{\mathrm{T}}$ (Werner \& Hall, 1988; Garvey et al., 1998; Santucci \& Wahl, 2003) and P. flavescens begin migrating between 8 and $40 \mathrm{~mm} L_{\mathrm{T}}$ (Urho, 1996).

Zooplankton were collected at the time of each trawl sample in Pelican Lake using a $2 \mathrm{~m}$ long tube sampler (Rabeni, 1996). Two zooplankton samples were taken at each quadrat and filtered through a $65 \mu \mathrm{m}$ mesh net, stored in $90 \%$ ethanol and then processed separately. Zooplankton were enumerated and identified to family for cladocerans (i.e. Bosminidae, Chydoridae and Daphnidae), and as cyclopoid or calanoid copepods and copepod nauplii. Each sample was diluted with water to a measured volume of $30 \mathrm{ml}$. Three sub-samples were taken with a $5 \mathrm{ml}$ Hensen-Stempel pipette and placed in a Ward counting wheel (www.wildco.com). Zooplankters were enumerated within each sub-sample and the total number of zooplankton of each taxon in a sample was calculated by dividing the number of organisms counted by the proportion of the sample volume processed. Density was calculated by multiplying the number of zooplankters of each taxon by the volume of the water filtered with the tube sampler.

The lake was bisected into two basins in a west to east fashion, yielding the longest fetch, so spatial differences of larval densities attributed to wind effects were more likely to be detected. Wind direction and intensity were obtained from the nearest remote automated weather station (Bessey recreation complex, Nebraska $84 \mathrm{~km}$ south-east of the lake; Fig. 1) that contained the most consistent data throughout the duration of the study (National Oceanic and Atmospheric Administration; www.raws.dri.edu). A closer weather station (Miller Field, Valentine, Nebraska), within $40 \mathrm{~km}$ of the lake, provided an incomplete weather database; wind direction was, however, similar and wind speeds over the course of the study (2004-2008) at both weather stations were highly correlated $(r=0 \cdot 88)$. A wind index $\left(I_{\mathrm{W}}\right)$ modified from George \& Edwards (1976) was used to characterize and incorporate information on wind intensity, direction and changes in direction, which assumes winds more immediate to the sampling event have more influence on the distribution of larval fishes. As such, wind speeds closer to the sampling event were more heavily weighted: $I_{\mathrm{W}}=\left(V_{1}+1 \times 2^{-1} V_{2}+\right.$ $\left.1 \times 4^{-1} V_{3}+1 \times 8^{-1} V_{4}+1 \times 16^{-1} V_{5}+1 \times 32^{-1} V_{6}\right)\left(D_{1}+1 \times 2^{-1} D_{2}+1 \times 4^{-1} D_{3}+1 \times\right.$ $8^{-1} D_{4}+1 \times 16^{-1} D_{5}+1 \times 32^{-1} D_{6}$ ), where $V_{i}$ is the wind velocity means for two consecutive hours with $V_{1}$ being the $2 \mathrm{~h}$ immediately prior to the sampling event and $V_{2}$ relates to the two consecutive hours prior to $V_{1}$ time set, etc. This allowed a quantitative estimate of wind 
events occurring over a $12 \mathrm{~h}$ period (i.e. six time sets $\times 2 \mathrm{~h}$ blocks $=12 \mathrm{~h}$ time period prior to sampling). In addition to examining wind events in a $12 \mathrm{~h}$ period prior to sampling, an $I_{\mathrm{W}}$ for 4,6 and 8 h blocks was calculated, resulting in 24,36 and $48 \mathrm{~h}$ time periods prior to sampling. Four different time periods were estimated because of the uncertainty at which time wind would no longer affect the movement of larval fishes. Wind direction $(D)$ was incorporated into $I_{\mathrm{D}}$ which assumes winds not within 50 cardinal degrees of the maximum fetch $\left(290^{\circ}\right.$, $110^{\circ}$ ) of the lake would probably not influence the movement of larval fishes between the east and west sides of the lake. A value of -1 was assigned to directions corresponding to those within 50 cardinal degrees of the east side of the lake's maximum fetch (i.e. $85-135^{\circ}$ ) and a value of +1 was assigned similarly to those within $50^{\circ}$ of the west side of the lake's maximum fetch (i.e. $265-315^{\circ}$; George \& Edwards, 1976). Larger negative values would correspond to high wind velocities from the south-east and large positive values, higher wind velocities from the north-west. All other directions were assigned a value of zero. Therefore, $D_{i}$ is the mean wind direction value for those same hour periods as described for the wind velocity estimates.

An ANOVA was used to detect differences in larval densities (number $100 \mathrm{~m}^{-3}$ ) and zooplankton densities according to the taxa Cladocera and Copepoda (number $1^{-1}$ ) between east and west sides of the lake. Larval P. flavescens and L. macrochirus densities were analysed according to three size classes: small $\left(<7 \mathrm{~mm}, L_{\mathrm{T}}\right)$, medium $\left(\geq 7\right.$ and $\left.<10 \mathrm{~mm}, L_{\mathrm{T}}\right)$ and large ( $\geq 10$ and $<13 \mathrm{~mm}, L_{\mathrm{T}}$ ). Size classes were chosen at a level that would maximize the precision in detail within the data set and minimize information lost due to inadequate sample sizes. Significant differences were assessed by adjusting alpha by the number of sampling dates (i.e. a sampling occasion where at least one larval fish was captured) each year for each species to account for the lack of independence among samples (i.e. 0.05 per number of sampling dates each year for each species; Allen \& DeVries, 1993). Due to the non-constant variability in the dependent variables, a mixed model was used (PROC MIXED; SAS Institute Inc.; www.sas.com). The maximum likelihood method was used because it allowed for unbalanced designs (e.g. more quadrants sampled on one side of the lake; Littell et al., 1996). The proportion of larval $P$. flavescens and L. macrochirus size classes, based on $1 \mathrm{~mm} L_{\mathrm{T}}$ groups, captured on the east and west side of the lake, was evaluated for each year sampled. Data were analysed using a graphical approach and were limited to years when $>300$ larvae were sampled and size bins contained a total sample size of $>9$ (D. F. Markle, unpubl. data). This approach potentially allows determination of the area of the lake in which most spawning occurs. For example, if one side of the lake contains a significant portion of smaller larvae than the other, it may suggest more spawning occurred there resulting in a higher accumulation of smaller sized larvae. Zooplankton data were analysed according to crustacean group (i.e. Cladocera and Copepoda) as these groups are most important during the early life stages of both L. macrochirus and P. flavescens (Welker et al., 1994; Graeb et al., 2004). Larval L. macrochirus, $P$. flavescens and zooplankton densities were $\log _{10}(x+1)$ transformed to better approximate normality.

To further evaluate the role of wind influencing the spatial distribution of larvae and zooplankton prey in Pelican Lake, a binary response code was given to each sampling date representing the side of the lake with a larger point estimate of larval fishes according to size class and zooplankton taxa Cladocera and Copepoda. A larger point estimate of larval fishes or prey on the east side of the lake was given a value of one and conversely a value of zero represented a larger point estimate on the west side of the lake. Logistic regression (PROC LOGISTIC; SAS Institute Inc.) was then used to determine if $I_{\mathrm{W}}$ values (i.e. independent variable) could predict the probability of more larval fishes being distributed on the east or west sides of the lake. Separate models were evaluated for each larval size class for each species and different time periods prior to sampling (i.e. 12, 24, 36 and $48 \mathrm{~h}$ ). An alpha of 0.05 was used to determine significant differences.

\section{RESULTS}

During the 2004-2008 sampling seasons, $48 \mathrm{~h}$ prior to sampling larval fishes, primary wind direction was predominantly from the south (11/51 sampling events), 


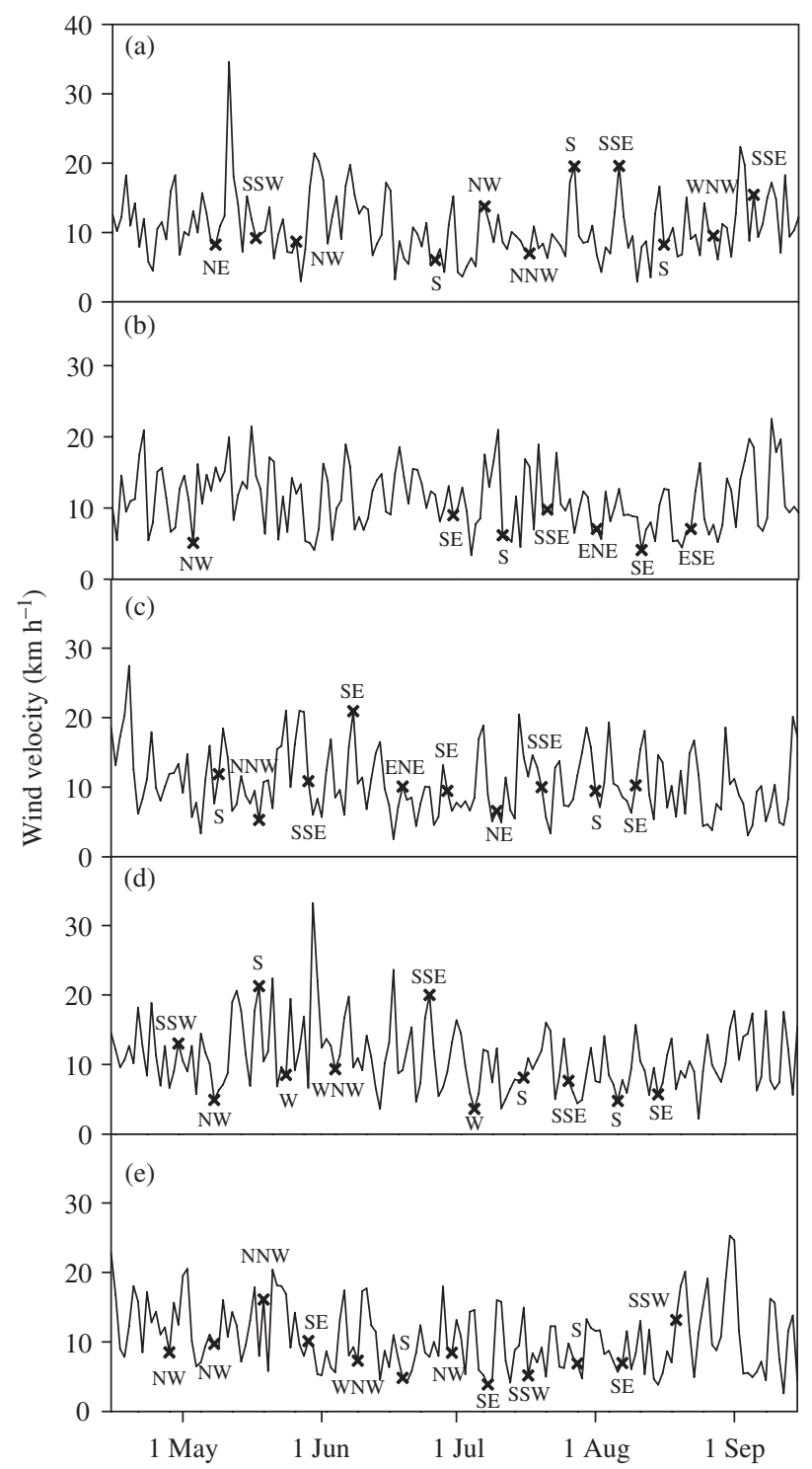

FIG. 2. Mean daily wind velocities recorded at the Bessey weather station in (a) 2004, (b) 2005, (c) 2006, (d) 2007 and (e) 2008 ( $\mathbf{X}$, sampling dates). Letters correspond to dominant cardinal wind direction $48 \mathrm{~h}$ prior to sampling event.

followed by the south-east (9/51 sampling events; Fig. 2). Daily sustained wind velocities ranged from 2.2 to $34.6 \mathrm{~km} \mathrm{~h}^{-1}$ (Fig. 2). Mean daily wind velocities over the duration of the sampling season ranged between 9.9 and $10.9 \mathrm{~km} \mathrm{~h}^{-1}$.

The highest observed mean density of all size classes combined for larval P. flavescens recorded on the east side of the lake was $1307 \mathrm{~m}^{-3}$ on 29 May 2008, and the highest density observed on the west side of the lake was $1107 \mathrm{~m}^{-3}$ on 9 June 2008, in the years examined. There was no significant difference (ANOVA, 


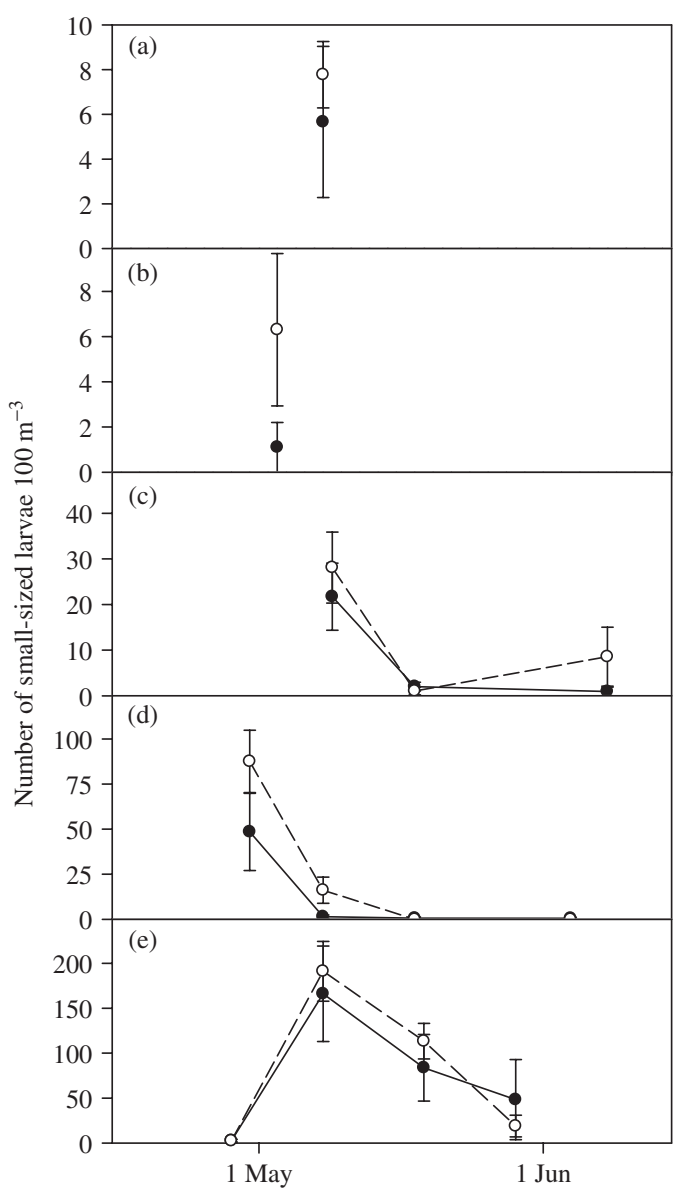

FIg. 3. Mean \pm s.E. density of small-sized ( $<7 \mathrm{~mm}$ total length, $\left.L_{\mathrm{T}}\right)$ larval Perca flavescens on east $(-)$ and west (O) sides of Pelican Lake in (a) 2004, (b) 2005, (c) 2006, (d) 2007 and (e) 2008.

$n=13$ sampling dates, $P>0.05)$ in spatial densities of small-sized $P$. flavescens larvae during 2004-2008 (Fig. 3). Medium-sized P. flavescens larval density was significantly higher on the west side of Pelican Lake on 18 May 2006 (ANOVA, d.f. $=1,8, P<0.01$ ) and on 8 May 2008 (ANOVA, d.f. $=1,7, P<0.01$ ) compared to the east side of the lake (Fig. 4). Densities of large-sized P. flavescens larvae were greatest on the west side of the lake on 18 May 2006 (ANOVA, d.f. $=1,8, P<0.01$ ) and on 9 June 2008 (ANOVA, d.f. $=1,8, P<0.01$ ) compared to the east side of the lake (Fig. 5). Significant larval $P$. flavescens spatial density differences were not detected on any other sampling dates for medium- and large-sized larvae (ANOVA, $n=11$ sampling dates each, $P>0 \cdot 05$; Figs 4 and 5).

Total larval L. macrochirus densities (i.e. all size classes combined) were highest on the east side of the lake on 20 July 2006 at $2055 \mathrm{~m}^{-3}$ and highest on the west side at $3290 \mathrm{~m}^{-3}$ on 17 July 2008 from 2004 to 2008. A higher density of small-sized larval L. macrochirus was observed on the west side of the lake on 8 August 2004 (ANOVA, d.f. $=1,8, P<0.01$ ) and 16 July 2007 (ANOVA, d.f. $=1,8, P<0 \cdot 01$ ) 


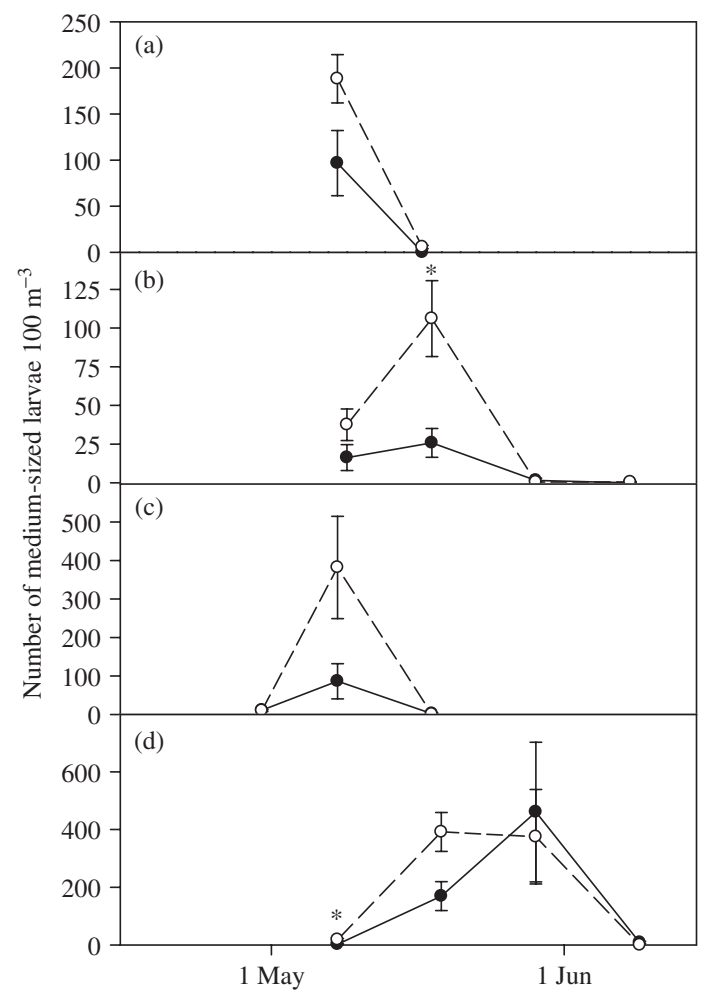

FIG. 4. Mean \pm S.E. density of medium-sized ( $\geq 7$ and $<10 \mathrm{~mm}$ total length, $L_{\mathrm{T}}$ ) larval Perca flavescens on east ( and west $(O)$ sides of Pelican Lake in (a) 2004, (b) 2006, (c) 2007 and (d) 2008. *, dates on which significant differences $(P<0.05)$ were observed between east and west sides of the lake.

in comparison with the east side of the lake (Fig. 6). The west side of the lake compared to the east side contained a significantly higher density of medium-sized L. macrochirus on 16 August 2004 (ANOVA, d.f. $=1,8, P<0.01$ ) and 1 August 2006 (ANOVA, d.f. $=1,8, P<0.001$; Fig. 7). Large-sized L. macrochirus larvae were significantly higher in abundance on the west side of the lake on 11 August 2005 (ANOVA, d.f. $=1,8, P<0 \cdot 01$ ) compared to the east side of the lake (Fig. 8). Significant larval L. macrochirus spatial density differences were not detected (ANOVA, $P>0.05)$ on any other sampling dates for small- $(n=25)$, medium- $(n=30)$ and large-sized larvae ( $n=30$; Figs 6 to 8 ).

A higher proportion $(>68 \%)$ of small $\left(<7 \mathrm{~mm} L_{\mathrm{T}}\right)$ P. flavescens larvae was located on the west side of Pelican Lake compared to the east side of the lake in 2007. In addition, the west side of the lake compared to the east side contained a higher proportion of larger P. flavescens $\left(>10 \mathrm{~mm} L_{\mathrm{T}}\right)$ in $2004(>71 \%)$ and 2006 (>85\%; Fig. 9). Due to an inadequate sample size, spatial differences in the proportion of $P$. flavescens larvae lengths could not be evaluated for 2005. Lepomis macrochirus larvae did not exhibit any distinct relationships between the proportion of larvae and the associated lengths distributed between east and west sides of Pelican Lake from 2004 to 2008 (Fig. 10). Copepod density ranged from 6 to $2371^{-1}$ on the east side and 5 to $2831^{-1}$ on the west side of the lake. Copepod density was highest 


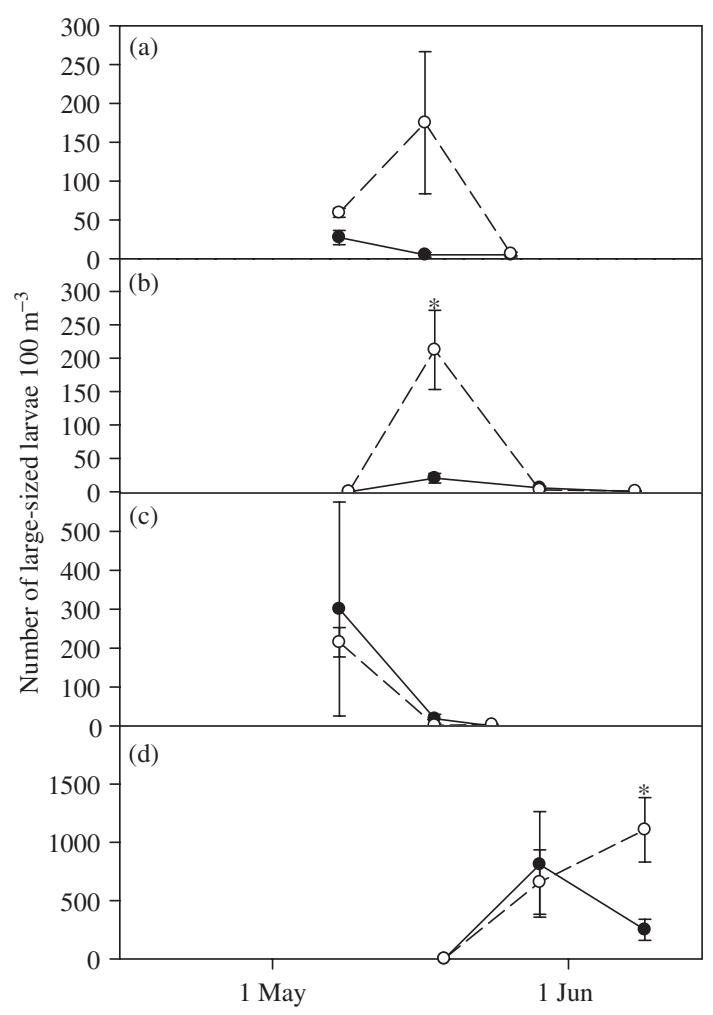

FIG. 5. Mean \pm S.E. density of large-sized ( $\geq 10$ and $<13 \mathrm{~mm}$ total length, $L_{\mathrm{T}}$ ) larval Perca flavescens on east (-) and west (O) sides of Pelican Lake in (a) 2004, (b) 2006, (c) 2007 and (d) 2008. *, dates on which significant differences $(P<0.05)$ were observed between east and west sides of the lake.

on the west side of the lake on 27 August 2004 (ANOVA, d.f. $=1,8, P<0 \cdot 01$ ) and 20 July 2006 (ANOVA, d.f. $=1,8, P<0 \cdot 01$ ), but higher on the east side of the lake on 11 August 2005 (ANOVA, d.f. $=1,8, P<0 \cdot 01$; Fig. 11). Copepod density did not differ between the east and west sides of the lake on any other sampling date (ANOVA, $n=70, P>0.05$ ). Cladoceran densities were $3-38371^{-1}$ on the east side of the lake and $3-35111^{-1}$ on the west side of the lake. There were no significant spatial differences in cladoceran densities during 2004-2008 in Pelican Lake (ANOVA, $n=73, P>0 \cdot 05$; Fig. 12).

There were no significant relationships $(P>0 \cdot 1)$ between wind index values at $12,24,36$ or $48 \mathrm{~h}$ before sampling and small-, medium- and large-sized larval $P$. flavescens and L. macrochirus densities. Similarly, no relationship existed $(P>0 \cdot 1)$ between $I_{\mathrm{W}}$ values and copepod and cladoceran densities during the 12 , 24,36 or $48 \mathrm{~h}$ period prior to sampling.

\section{DISCUSSION}

Spatial distribution patterns of larval fishes and their zooplankton prey in this small, vegetated, shallow lake were not associated with wind velocity or direction. 




FIG. 6. Mean \pm S.E. density of small-sized ( $<7 \mathrm{~mm}$ total length, $L_{\mathrm{T}}$ ) larval Lepomis macrochirus on east and west $(O$ ) sides of Pelican Lake in (a) 2004, (b) 2005, (c) 2006, (d) 2007 and (e) 2008. *, dates on which significant differences $(P<0.05)$ were observed between east and west sides of the lake.

Other studies that have documented larval fish transportation in relation to wind and current advections were in systems much larger than Pelican Lake (Dettmers et al., 2005; Auer \& Oyadomari, 2008; McKenna et al., 2008), with undoubtedly more complex wind-induced currents compared to the system in the present study. Most studies documenting the influence of wind as a transport mechanism in small lakes ( $<500$ ha) have focused on phytoplankton (George \& Edwards, 1976; George $\&$ Heaney, 1978) and few studies have exclusively focused on larval fishes (Coles, 1981). It was assumed that larval fishes would drift downwind in Pelican Lake, especially as wind velocities increased, because newly hatched larval $P$. flavescens cannot swim against water currents (Houde, 1969). George \& Edwards (1976) employed wind drogues in a small reservoir and found that the drogues drifted downwind at depths of 0.5 and $1.0 \mathrm{~m}$ (i.e. typically where larval fishes are distributed). 


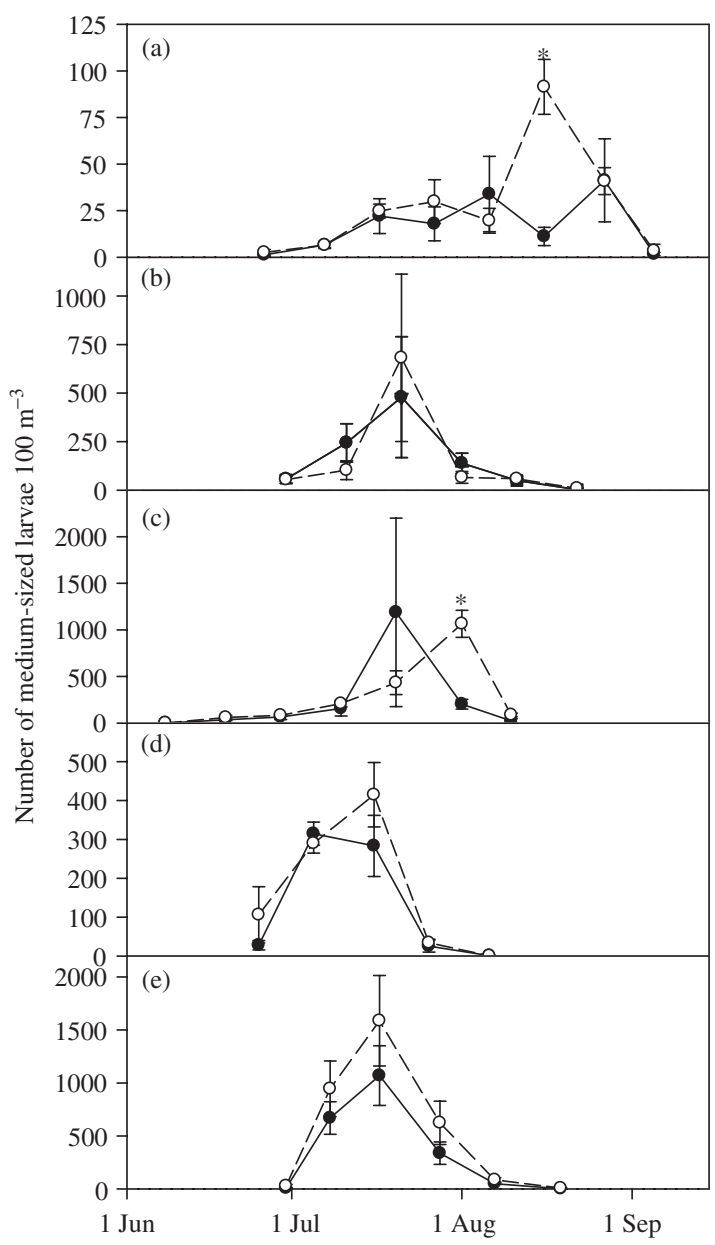

FIG. 7. Mean \pm S.E. density of medium-sized ( $\geq 7$ and $<10 \mathrm{~mm}$ total length, $L_{\mathrm{T}}$ ) larval Lepomis macrochirus on east ( and west (O) sides of Pelican Lake in (a) 2004, (b) 2005, (c) 2006, (d) 2007 and (e) 2008. $*$, dates on which significant differences $(P<0.05)$ were observed between east and west sides of the lake.

One potential reason for the lack of a relationship between wind and the spatial distribution of larval fishes in Pelican Lake could be related to the multiple emergent vegetation patches (mainly Scirpus spp.) interspersed across the main basin of the lake (Paukert \& Willis, 2002). Markle et al. (2009) speculated that larval suckers [shortnose sucker Chasmistes brevirostris Cope 1879 and Lost River sucker Deltistes luxatus (Cope 1879)] accumulated in emergent vegetation and thus were less subject to predation. They further suggested that the retention of larval fishes may be related to habitat variables such as vegetation, among others, in a large Oregon lake. If emergent vegetation acts as a buffer, inhibiting larval fish movement, spatial differences of larval fishes would not be detected in relation to wind in Pelican Lake, as these differences could be compromised by vegetation. Spatial distributions of larval fishes could potentially still be related to wind in shallow lakes where the 


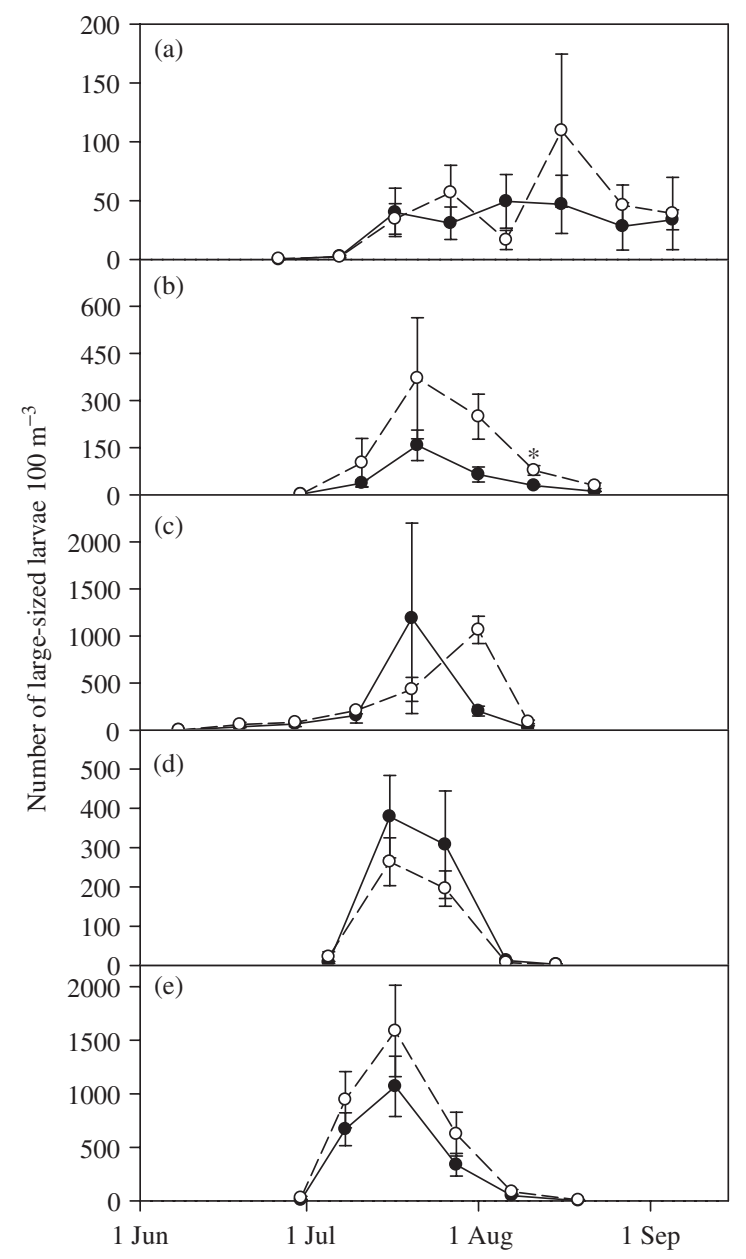

Fig. 8. Mean \pm s.E. density of large-sized ( $\geq 10$ and $<13 \mathrm{~mm}$ total length, $\left.L_{\mathrm{T}}\right)$ larval Lepomis macrochirus on east (-) and west (O) sides of Pelican Lake in (a) 2004, (b) 2005, (c) 2006, (d) 2007 and (e) 2008. $*$, dates on which significant differences $(P<0.05)$ were observed between east and west sides of the lake.

main lake basin is void of vegetation. Future research should focus on the effects of vegetation in small lakes and its ability to retain larval fishes or restrict wind-induced currents.

Wind-generated currents in Pelican Lake could be more complex than initially thought, which would lead to difficulties detecting any spatial patterns in larval fish densities. Livingstone (1954) proposed that wind currents in an isothermal lake, such as Pelican Lake, generate currents in the main lake basin in the direction of the wind but are balanced by an opposite feedback current along the nearshore areas of the lake. This type of wind-induced water current pattern was also found by Verhagen (1994); the longshore gradient return direction was, however, found to be opposite from that reported by Livingstone (1954) and was attributed in part to the shoreline gradient. The shoreline gradient of Pelican Lake is best described as a gentle slope 


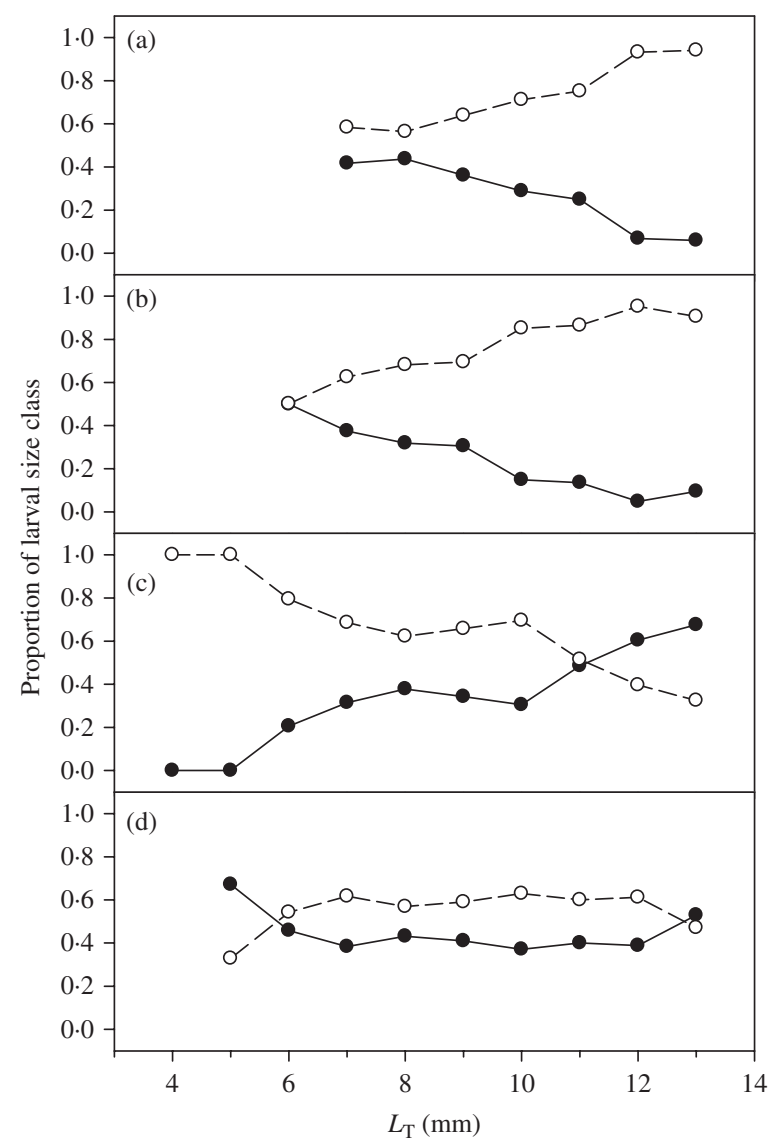

FIg. 9. Proportion of larval Perca flavescens size classes (per $1 \mathrm{~mm}$ total length, $L_{\mathrm{T}}$ ) captured on east and west $(\mathrm{O}$ ) sides of Pelican Lake in (a) 2004, (b) 2006, (c) 2007 and (d) 2008 (no data in 2005 due to low sample sizes).

and highly vegetated with emergents (in most cases out to $30 \mathrm{~m}$; unpubl. data), in which an opposite feedback may be modified and less pronounced than in other shallow lakes because vegetation can influence water currents (Leonard \& Luther, 1995; Nepf et al., 1997).

Although spatial larval densities could not be related to wind effects, these differences could be attributed to spawning sites for adult $P$. flavescens. Higher densities of adults spawning in the west side of the lake could produce more larvae, thus increasing the chance of detecting more larval fishes on this side of the lake. For $P$. flavescens in 2007, a higher proportion of smaller larvae was found on the west side of the lake, potentially corresponding to increased spawning activity in this area; this relationship was not, however, supported in other years examined. Higher catches of adult $P$. flavescens have been observed on the west side of Pelican Lake (J. C. Jolley \& M. A. Kaemingk, unpubl. data), concomitant with the observed spatial density differences. Alternatively, L. macrochirus appear to be utilizing the entire lake for spawning, as indicated by the lack of disproportionate abundances of each 


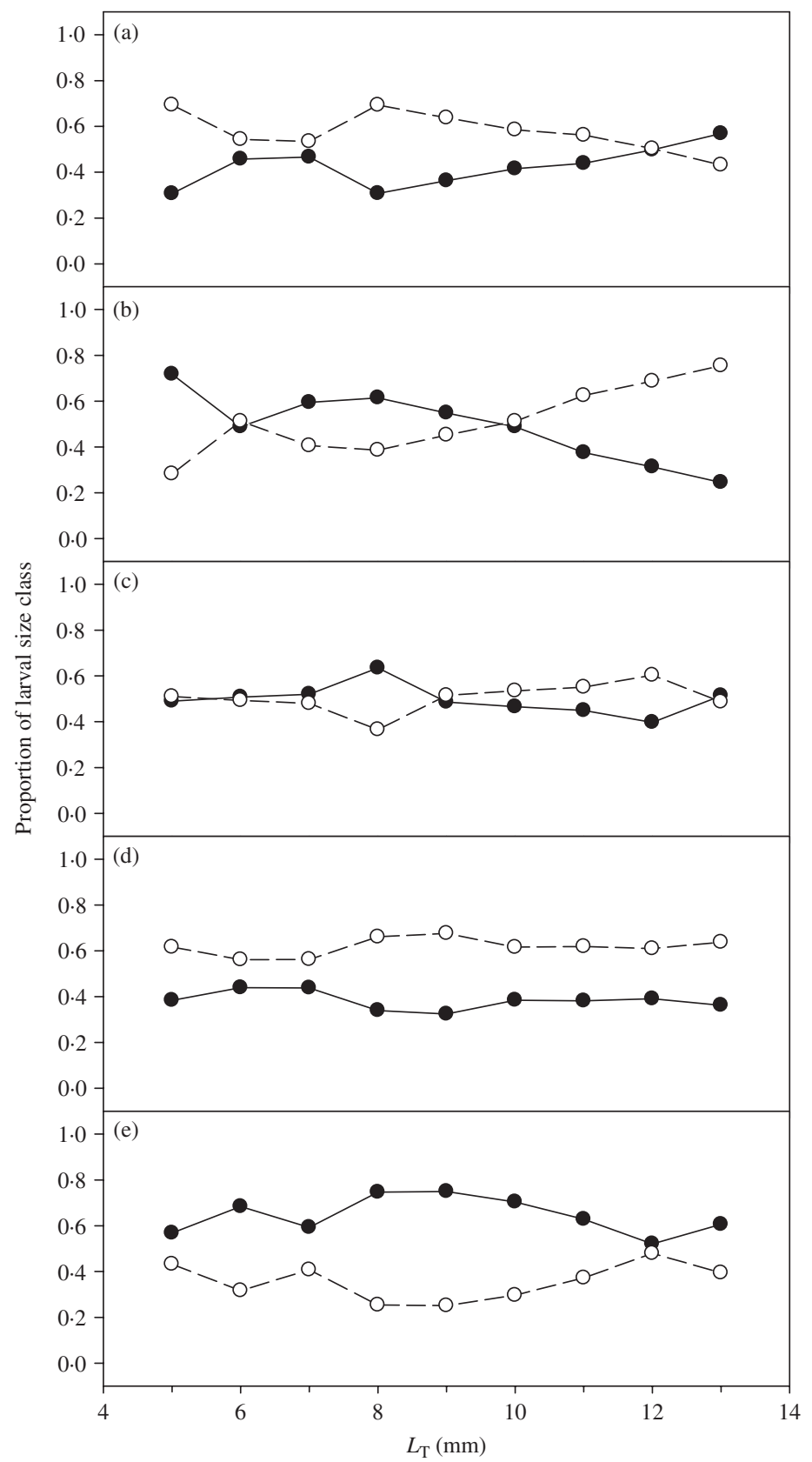

FIG. 10. Proportion of larval Lepomis macrochirus size classes (per $1 \mathrm{~mm}$ total length, $L_{\mathrm{T}}$ ) captured on east (-) and west (O) sides of Pelican Lake in (a) 2004, (b) 2005, (c) 2006, (d) 2007 and (e) 2008.

size class of larvae captured on the east and west side of the lake. This further suggests that spatial density differences of larval L. macrochirus are a result of something other than spawning location, such as wind effects, and are mediated by vegetation 




FIG. 11. Mean \pm S.E. copepod densities on east $(-)$ and west $(O)$ sides of Pelican Lake in (a) 2004, (b) 2005, (c) 2006, (d) 2007 and (e) 2008. *, dates on which significant differences $(P<0.05)$ were observed between east and west sides of the lake.

interspersed throughout the lake. Perch Perca fluviatilis L. 1758 in Llyn Tegid Lake, north Wales also spawned in the upwind side of the lake (Coles, 1981), similar to Pelican Lake where prevailing winds are from the north-west. The north-west end of Pelican Lake is also more likely to experience warmer water temperatures because it is more protected, thus having the potential to attract higher densities of spawning $P$. flavescens. Other studies have found larval $P$. fluviatilis spatial density 


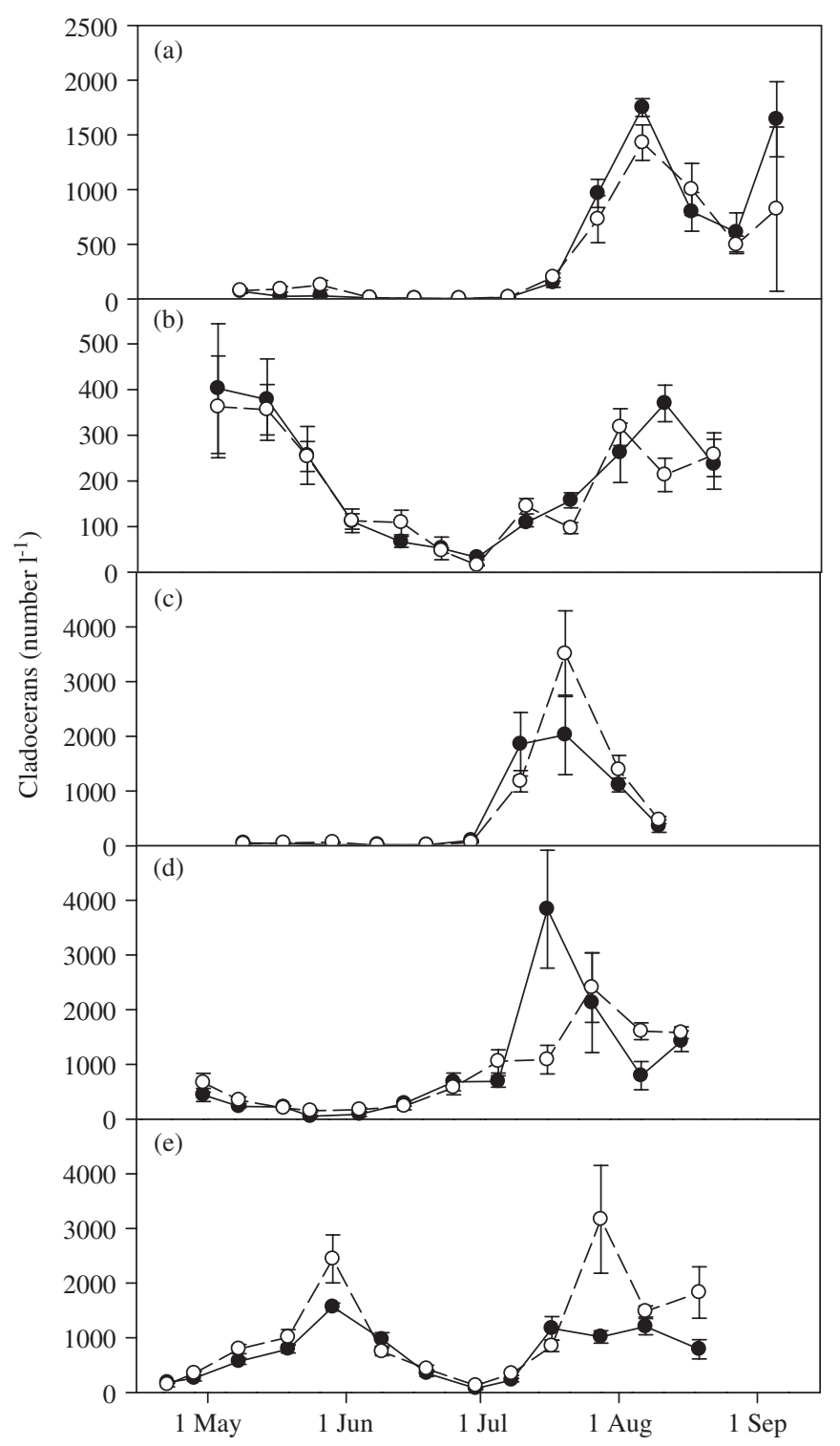

FIG. 12. Mean \pm S.E. cladoceran densities on east $(-$ ) and west $(O)$ sides of Pelican Lake in (a) 2004, (b) 2005, (c) 2006, (d) 2007 and (e) 2008. No significant differences were observed on any sampling dates.

relationships to spawning ground locations (Coles et al., 1977; Coles, 1981) and have attributed their subsequent distribution to wind-induced effects (Coles, 1981).

There was much variability in $P$. flavescens recruitment and some degree of variability in L. macrochirus recruitment in Pelican Lake during 2004-2008 (Jolley, 2009). This variability in recruitment does not appear to be a result of a spatial mismatch between $P$. flavescens and L. macrochirus larvae and associated zooplankton prey (i.e. higher densities of prey on opposite sides of the lake where higher 
densities of larvae were observed). Recruitment variability may, however, be a result of low copepod densities during the early larval stages, with most sampling dates (53/60 east side, 48/60 west side) exhibiting mean densities of copepods $<1001^{-1}$. Zooplankton densities $<100$ organisms $1^{-1}$ are below the suggested threshold that results in reduced larval fish growth and increased mortality (Werner \& Blaxter, 1980; Eldridge et al., 1981; Li \& Mathias, 1982; Dettmers et al., 2003). In addition, half of the sampling dates fell below 50 copepods $1^{-1}$. Conversely, fewer sampling dates (19/60 east side, 15/60) yielded cladoceran densities below this threshold, and a majority far exceeded this density.

Perca flavescens larvae in Pelican Lake during 2004 initially selected copepods, whereas L. macrochirus larvae selected Bosmina sp. and copepods during 2004 and 2005 (Jolley et al., 2010). Because of the importance of copepods during the first feeding of larval L. macrochirus and P. flavescens in Pelican Lake and the lower density estimates of this zooplankton taxon, it is possible that growth could be compromised and ultimately result in higher mortality rates. Zooplankton biomass has been related to early growth of larval black crappie Pomoxis nigromaculatus (Lesueur 1829) (Bunnell et al., 2003); however, Garvey et al. (2002) failed to find any relationship between zooplankton abundance and larval L. macrochirus survival. If copepod densities are adequate and do not inhibit initial larval growth, there does not appear to be any spatial or temporal mismatch between these larval fishes and prey in Pelican Lake, as peak P. flavescens and L. macrochirus larval abundances commonly matched peak abundances of copepods and Bosmina sp. (L. macrochirus) on a temporal scale (Jolley et al., 2010) during 2004-2008.

Despite low copepod densities observed on several sampling dates, larval fishes may encounter localized (i.e. on a metre scale) patches of dense zooplankton and density estimates recorded on the spatial scale used in this study may not ultimately reflect absolute densities encountered by larval fishes in this study (Young et al., 2009). Spatial differences in zooplankton densities were more pronounced when comparing samples collected between the east and west sides of the lake in contrast to those taken within the east or west sides of the lake, suggesting more large-scale than small-scale variability (unpubl. data). Furthermore, only on three sampling dates over 5 years was there any evidence of spatial differences in copepod densities and no sampling dates differed with respect to cladoceran densities. The topic of spatial and temporal overlap of predators and prey on a fine spatial scale (i.e. $1 \mathrm{~m}$ ) warrants further investigation.

This study represents one of the few studies to examine wind effects on larval fishes and their distribution in a small, shallow lake and the findings indicate spatial differences are evident, but are not at all related to wind events. The spatial overlap between predators and prey in this system appears to be congruent and thus a spatial mismatch is not likely; prey densities over this spatial scale appear, however, to be in the range of other reported studies where larval growth was negatively affected. Future studies should aim to explain spatial differences in the light of other variables (i.e. vegetation and spawning location) and how these interact with food availability over a smaller spatial scale.

We thank all the technicians who assisted in the field and laboratory. M. Lindvall and Valentine National Wildlife Refuge provided access to Pelican Lake. D. Graham, D. Hartmann, D. Krueger and the Valentine State Fish Hatchery for assistance. Funding for this project was 
provided by the Nebraska Game and Parks Commission through the Federal Aid in Sport Fish Restoration Project F-118-R.

\section{References}

Allen, M. S. \& DeVries, D. R. (1993). Spatial and temporal heterogeneity of larval shad in a large impoundment. Transactions of the American Fisheries Society 122, 1070-1079.

Anderson, M. A., Fisher, S. J. \& Willis, D. W. (1998). Relationship between larval and juvenile yellow perch abundance in eastern South Dakota glacial lakes. North American Journal of Fisheries Management 18, 989-991.

Auer, N. A. (Ed.) (1982). Identification of larval fishes of the Great Lakes basin with emphasis on the Lake Michigan drainage. Great Lakes Fishery Commission, Special Publication 82-3.

Auer, N. A. \& Oyadomari, J. K. (2008). Transport and growth of larval cisco (Coregonus artedi) in the Keweenaw Current region of Lake Superior. Canadian Journal of Fisheries and Aquatic Sciences 65, 1447-1458.

Beard, T. D. (1982). Population Dynamics of Young-of-the-Year Bluegill. Technical Bulletin 127. Madison, WI: Wisconsin Department of Natural Resources.

Beauchamp, D. A., Sergeant, C. J., Mazur, M. M., Scheuerell, J. M., Schindler, D. E., Scheuerell, M. D., Fresh, K. L., Seiler, D. E. \& Quinn, T. P. (2004). Spatial-temporal dynamics of early feeding demand and food supply for sockeye salmon fry in Lake Washington. Transactions of the American Fisheries Society 133, 1014-1032.

Bunnell, D. B., González, M. J. \& Stein, R. A. (2003). Zooplankton biomass enhances growth, but not survival, of first-feeding Pomoxis spp. larvae. Canadian Journal of Fisheries and Aquatic Sciences 60, 1314-1323.

Cargnelli, L. M. \& Gross, M. R. (1996). The temporal dimension in fish recruitment: birth date, body size, and size-dependent survival in a sunfish (bluegill: Lepomis macrochirus). Canadian Journal of Fisheries and Aquatic Sciences 53, 360-367.

Chick, J. H. \& Van Den Avyle, M. J. (1999). Zooplankton variability and larval striped bass foraging: evaluating potential match-mismatch regulation. Ecological Applications 9, $320-334$.

Clady, M. \& Hutchinson, B. (1975). Effect of high winds on eggs of yellow perch, Perca flavescens, in Oneida Lake, New York. Transactions of the American Fisheries Society 104, 524-525.

Clady, M. D. (1976). Influence of temperature and wind on the survival of early stages of yellow perch, Perca flavescens. Journal of the Fisheries Research Board of Canada 33, 1887-1893.

Coles, T. F. (1981). The distribution of perch, Perca fluviatilis, L., throughout their first year of life in Llyn Tegid, North Wales. Journal of Fish Biology 18, 15-30.

Coles, T. F., Swinney, G. N. \& Jones, J. W. (1977). A technique for determining the distribution of pelagic fish larvae. Journal of Fish Biology 11, 151-159.

Cushing, D. H. (1975). Marine Ecology and Fisheries. Cambridge: Cambridge University Press.

Cushing, D. H. (1990). Plankton production and year-class strength in fish populations: an update of the match/mismatch hypothesis. Advances in Marine Biology 26, 249-293.

Dettmers, J. M., Raffenberg, M. J. \& Weis, M. K. (2003). Exploring zooplankton changes in southern Lake Michigan: implications for yellow perch recruitment. Journal of Great Lakes Research 29, 355-364.

Dettmers, J. M., Janssen, J., Pientka, B., Fulford, R. S. \& Jude, D. J. (2005). Evidence across multiple scales for offshore transport of yellow perch (Perca flavescens) larvae in Lake Michigan. Canadian Journal of Fisheries and Aquatic Sciences 62, 2683-2693.

Dewey, K. F. (1977). Wind. In Climatic Atlas of Nebraska (Lawson, M. P., Dewey, K. F. \& Meyers, R. E., eds), pp. 72-74. Lincoln, NE: University of Nebraska Press.

Eldridge, M. B., Whipple, J. A., Eng, D., Bowers, M. J. \& Jarvis, B. M. (1981). Effects of food and feeding factors on laboratory-reared striped bass. Transactions of the American Fisheries Society 110, 112-120. 
Garvey, J. E., Wright, R. A. \& Stein, R. A. (1998). Overwinter growth and survival of age-0 largemouth bass (Micropterus salmoides): revisiting the role of body size. Canadian Journal of Fisheries and Aquatic Sciences 55, 2414-2424.

Garvey, J. E., Herra, T. P. \& Leggett, W. C. (2002). Protracted reproduction in sunfish: the temporal dimension in fish recruitment revisited. Ecological Applications 12, 194-205.

George, D. G. \& Edwards, R. W. (1976). The effect of wind on the distribution of chlorophyll a and crustacean plankton in a shallow eutrophic reservoir. Journal of Applied Ecology 13, 667-690.

George, D. G. \& Heaney, S. I. (1978). Factors influencing the spatial distribution of phytoplankton in a small productive lake. Journal of Ecology 66, 133-155.

Graeb, B. D. S., Dettmers, J. M., Wahl, D. H. \& Cáceres, C. E. (2004). Fish size and prey availability affect growth, survival, prey selection, and foraging behavior of larval yellow perch. Transactions of the American Fisheries Society 133, 504-514.

Holland-Bartels, L. E., Littlejohn, S. K. \& Huston, M. L. (1990). A Guide to Larval Fishes of the Upper Mississippi River. La Crosse, WI: US Fish and Wildlife Service, National Fisheries Research Center.

Houde, E. D. (1969). Sustained swimming ability of larvae of walleye and yellow perch. Journal of the Fisheries Research Board of Canada 26, 1647-1659.

Isermann, D. A. \& Willis, D. W. (2008). Emergence of larval yellow perch, Perca flavescens, in South Dakota lakes: potential implications for recruitment. Fisheries Management and Ecology 15, 259-271.

Jolley, J. C. (2009). Recruitment of bluegill and yellow perch in Nebraska Sandhills lakes: integrating multiple life stages. PhD Dissertation, South Dakota State University, Brookings, SD, USA.

Jolley, J. C., Willis, D. W. \& Holland, R. S. (2010). Match-mismatch regulation for bluegill and yellow perch larvae and their prey in Sandhill lakes. Journal of Fish and Wildlife Management 1, 73-85. doi: 10.3996/062010-JFWM-018

Kallemeyn, L. W. (1987). Correlations of regulated water levels and climatic factors with abundance of young-of-year walleye and yellow perch in four lakes in Voyageurs National Park. North American Journal of Fisheries Management 7, 513-521.

Leonard, L. \& Luther, M. (1995). Flow hydrodynamics in tidal march canopies. Limnology and Oceanography 40, 1474-1484.

Li, S. \& Mathias, J. A. (1982). Causes of high mortality among cultured larval walleyes. Transactions of the American Fisheries Society 111, 710-721.

Littell, R. C., Milliken, G. A., Stroup, W. W. \& Wolfinger, R. D. (1996). SAS System for Mixed Models. Cary, NC: SAS Institute Inc.

Livingstone, D. A. (1954). On the orientation of lake basins. American Journal of Science 252, 547-554.

Markle, D. F., Reithel, S. A., Crandall, J., Wood, T. M., Tyler, T. J., Terwilliger, M. R. \& Simon, D. C. (2009). Larval fish transport and retention, and the importance of location for juvenile fish recruitment in Upper Klamath Lake, Oregon. Transactions of the American Fisheries Society 138, 328-347.

McKenna, J. E. Jr., Davis, B. M., Fabrizio, M. C., Savino, J. F., Todd, T. N. \& Bur, M. (2008). Ichthyoplankton assemblages of coastal west-central Lake Erie and associated habitat characteristics. Journal of Great Lakes Research 34, 755-769.

Miller, T. J., Crowder, L. B., Rice, J. A. \& Marschall, E. A. (1988). Larval size and recruitment mechanisms in fishes: toward a conceptual framework. Canadian Journal of Fisheries and Aquatic Sciences 45, 1657-1670.

Mitzner, L. (1991). Effect of environmental variables upon crappie young, year-class strength, and the sport fishery. North American Journal of Fisheries Management 11, 534-542.

Nepf, H. M., Sullivan, J. A. \& Zavistoski, R. A. (1997). A model for diffusion within emergent vegetation. Limnology and Oceanography 42, 1735-1745.

Paukert, C. P. \& Willis, D. W. (2002). Seasonal and diel habitat selection by bluegills in a shallow natural lake. Transactions of the American Fisheries Society 131, 1131-1139.

Phelps, Q. E., Graeb, B. D. S. \& Willis, D. W. (2008). Influence of the Moran effect on spatiotemporal synchrony in common carp recruitment. Transactions of the American Fisheries Society 137, 1701-1708. 
Pope, K. L., Willis, D. W. \& Lucchesi, D. O. (1996). Differential relations of age-0 black crappie and yellow perch to climatological variables in a natural lake. Journal of Freshwater Ecology 11, 345-350.

Puvanendran, V. \& Brown, J. (1999). Foraging, growth and survival of Atlantic cod larvae reared in different prey concentrations. Aquaculture 175, 77-92.

Rabeni, C. F. (1996). Invertebrates. In Fisheries Techniques, 2nd edn (Murphy, B. R. \& Willis, D. W., eds), pp. 335-351. Bethesda, MD: American Fisheries Society.

Romare, P., Berg, S., Lauridsen, T. \& Jeppesen, E. (2003). Spatial and temporal distribution of fish and zooplankton in a shallow lake. Freshwater Biology 48, 1353-1362.

Roseman, E. F., Taylor, W. W., Hayes, D. B., Knight, R. L. \& Haas, R. C. (2001). Removal of walleye eggs from reefs in Western Lake Erie by a catastrophic storm. Transactions of the American Fisheries Society 130, 341-346.

Saksena, V. P. \& Houde, E. D. (1972). Effect of food level on the growth and survival of laboratory reared larvae of bay anchovy (Anchoa mitchillii Valenciennes) and scaled saline (Harengula pensacolae Good and Bean). Journal of Experimental Marine Biology and Ecology 8, 249-258.

Santucci, V. J. Jr. \& Wahl, D. H. (2003). The effects of growth, predation, and first-winter mortality on recruitment of bluegill cohorts. Transactions of the American Fisheries Society 132, 346-360.

Seljeset, O., Vollset, K. W., Folkvord, A. \& Geffen, A. J. (2010). The role of prey concentration and size range in the growth and survival of larval cod. Marine Biology Research 6, 251-262.

Tsai, C. (1991). Prey density requirements of the striped bass, Morone saxatilis (Walbaum) larvae. Estuaries 14, 207-217.

Urho, L. (1996). Habitat shifts of perch larvae as survival strategy. Annales Zoologici Fennici 33, 329-340.

Verhagen, J. H. G. (1994). Modeling phytoplankton patchiness under the influence of winddriven currents in lakes. Limnology and Oceanography 39, 1551-1565.

Ward, M. J., Anderson, M. R., Fisher, S. J., Isermann, D. A., Phelps, Q. E. \& Willis, D. W. (2004). Relations between climatological variables and larval yellow perch abundance in eastern South Dakota glacial lakes. Journal of Freshwater Ecology 19, 213-218.

Welker, M. T., Pierce, C. L. \& Wahl, D. H. (1994). Growth and survival of larval fishes: roles of competition and zooplankton abundance. Transactions of the American Fisheries Society 123, 703-717.

Werner, R. G. (1967). Intralacustrine movements of bluegill fry in Crane Lake, Indiana. Transactions of the American Fisheries Society 96, 416-420.

Werner, R. G. \& Blaxter, J. H. S. (1980). Growth and survival of larval herring (Clupea harengus) in relation to prey density. Canadian Journal of Fisheries and Aquatic Sciences 37, 1063-1069.

Werner, E. E. \& Hall, D. J. (1988). Ontogenetic habitat shifts in bluegills: the foraging ratepredation risk trade-off. Ecology 69, 1352-1366.

Whiteside, M. C., Swindoll, C. M. \& Doolittle, W. L. (1985). Factors affecting the early life history of yellow perch, Perca flavescens. Environmental Biology of Fishes 12, 47-56.

Wilhite, D. A. \& Hubbard, K. G. (1989). Climate. In An Atlas of the Sand Hills (Bleed, A. \& Flowerday, C., eds), pp. 17-28. Lincoln, NE: University of Nebraska Conservation and Survey Division.

Young, K. V., Dower, J. F. \& Pepin, P. (2009). A hierarchical analysis of the spatial distribution of larval fish prey. Journal of Plankton Research 31, 687-700. 